Proc. Estonian Acad. Sci. Biol. Ecol., 2003, 52, 3, 193-204

\title{
Late summer vertical nutrient fluxes estimated from direct turbulence measurements: a Gulf of Finland case study
}

\author{
Madis-Jaak Lilover ${ }^{\mathrm{a}^{*}}$, Jaan Laanemets ${ }^{\mathrm{a}}$, Tiit Kullas ${ }^{\mathrm{b}}$, Adolf Stips ${ }^{\mathrm{c}}$, \\ and Kaisa Kononen ${ }^{\mathrm{d}}$ \\ ${ }^{\text {a }}$ Marine Systems Institute, Tallinn Technical University, Akadeemia tee 21, 12618 Tallinn, Estonia \\ ${ }^{\mathrm{b}}$ Estonian Marine Institute, University of Tartu, Mäealuse 10A, 12618 Tallinn, Estonia; tq@ sea.ee \\ c Inland and Marine Waters Unit, CEC Joint Research Centre, TP 272I-21020 Ispra, Italy; \\ adolf.stips@jrc.it \\ d Academy of Finland, Vilhonvuorenkatu 6, FIN-00120 Helsinki, Finland; kaisa.kononen@aca.fi
}

Received 6 January 2003, in revised form 25 April 2003

\begin{abstract}
Profiles of nutrient concentrations, current velocity, density, and microstructure were obtained at the entrance to the Gulf of Finland in July 1998. The averaged vertical eddy diffusivity, $K_{\rho}$, had high values $\left(2-8 \times 10^{-3} \mathrm{~m}^{2} \mathrm{~s}^{-1}\right)$ for three microstructure measurement series in different wind forcing regimes in the upper mixed layer (UML) and remained scattered between $10^{-6}$ and $10^{-4} \mathrm{~m}^{2} \mathrm{~s}^{-1}$ below the seasonal pycnocline. The amount of nutrients transported from below the pycnocline into the UML is calculated by a simplified diffusion equation using profiles of $K_{\rho}$ and phosphate and nitrate concentrations. The estimated nutrient input carried a clear excess of phosphate due to a large spacing between the phosphocline and the nitracline.
\end{abstract}

Key words: eddy diffusivity, turbulent fluxes, cyanobacterial bloom, Gulf of Finland.

\section{INTRODUCTION}

The origin of requisite phosphorus for nitrogen-fixing cyanobacteria in the late summer nutrient depleted upper layer is essential for understanding the initiation and development of frequently observed massive blooms in the Baltic Sea. Larsson et al. (2001) showed that Aphanizomenon sp. seed population stores part of the

* Corresponding author, madis@phys.sea.ee 
phosphorus excess left after the spring bloom before the actual growth starts. The storage capacity of the other dominating species, Nodularia spumigena, is still unclear and therefore different alternative sources are under discussion. It has been suggested that Nodularia relies on regenerated phosphorus (e.g. Kononen et al., 1996) or on phosphorus transported from the deeper nutrient rich water by physical processes such as upwelling and vertical turbulent mixing (e.g. Larsson et al., 2001). The actual estimates of the amounts of phosphorus transported by turbulent mixing into the surface layer are rare because of the shortage of direct measurements of turbulence. Thus, the importance of turbulent mixing in the summer surface layer supply with phosphorus is still not established. Earlier the vertical turbulent mixing in the Baltic Sea was studied experimentally by the tracer technique (e.g. Kullenberg, 1977) or by using the so-called budget models (e.g. Hela, 1966; Shaffer, 1979; Kullenberg, 1982; Rahm, 1985; Matthäus, 1990). Gade (1970) suggested the eddy diffusivity in a stagnant semi-enclosed basin as a function of the buoyancy frequency. Stigebrandt (1987) parameterized the eddy diffusivity as a function inversely proportional to the buoyancy frequency in the Baltic Sea deep water. Only a few regional studies of turbulence measured with fast-response sensors have been reported so far. In 1987 measurements of turbulence were carried out at the eastern slope of the Gotland Basin (Lilover \& Nabatov, 1990) and in 1995 at the coastal margin of the Arkona Basin (Zülicke et al., 1998). In both papers the mean eddy diffusivity was estimated for certain depth(s) only and no vertical distribution of eddy diffusivity was presented.

In the present paper the estimates of turbulent nutrient fluxes rely on the vertical distribution of eddy diffusivity calculated from the microstructure measurements and on simultaneously sampled nutrient concentration profiles. The potential of turbulent mixing as an agent supplying the surface layer with nutrients, especially with phosphorus in summer, is discussed.

\section{MATERIALS AND METHODS}

\section{Site description}

The study site is located at the entrance to the Gulf of Finland (Fig. 1). The gulf is a typical estuarine environment: the salinity in the surface layer ranges from approximately 7 PSU at the entrance to fresh water in the eastern end of the gulf. The general circulation is cyclonic in the gulf and varies strongly due to the wind forcing (Palmén, 1930). The inertial oscillations and seiches are also an important part of the non-stationary circulation pattern (Alenius et al., 1998). The tidal oscillations of the sea level have minor importance to the dynamics of the Baltic Sea (Kullenberg, 1981). A prominent phenomenon in the entrance area is a quasi-permanent density front parallel to the Estonian coast, formed by intrusion of saltier northern Baltic Proper water into the less saline gulf water (Pavelson et al., 1997). There are two pycnoclines in summer caused by the seasonal thermo- 


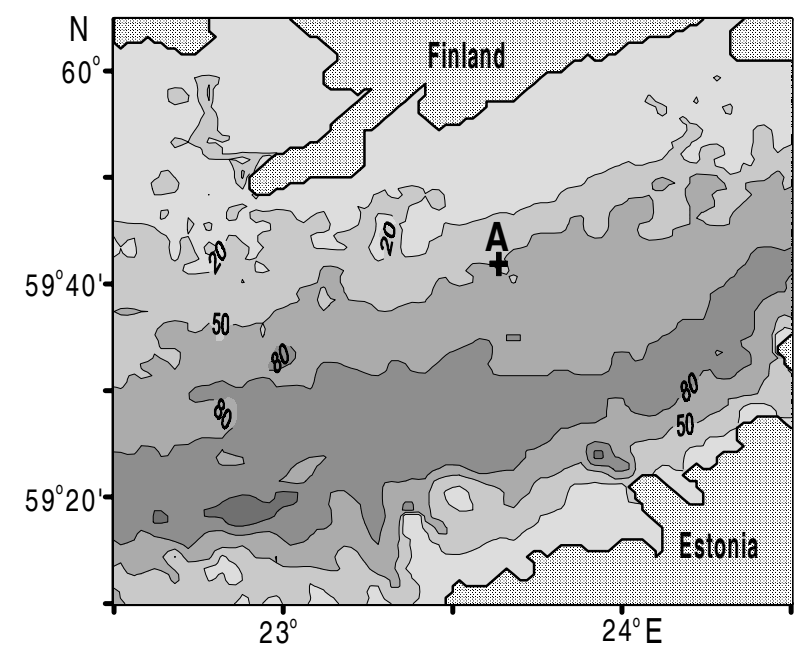

Fig. 1. The study site. The cross marks the location of the anchor station A. The isobath labels are given in metres.

cline in the upper layer and the permanent halocline situated at 50-60 m depth. The seasonal thermocline is the strongest in July-August and is usually observed at a depth of 10-20 m, so effectively restricting nutrient transport to the euphotic layer in summer.

\section{The data and methods}

The study was carried out with the general aim to investigate the influence of meso- and small-scale physical processes on to the initiation and development of cyanobacterial blooms. The measurements were conducted aboard the R/V Aranda (Finnish Institute of Marine Research) from 13 to 23 July 1998 in the entrance area to the Gulf of Finland. The data discussed further were gathered at an anchor station A $\left(59^{\circ} 42.5^{\prime} \mathrm{N}, 23^{\circ} 38.0^{\prime} \mathrm{E}\right)$. The basic data set includes the current velocity recorded by a bottom mounted Acoustic Doppler Current Profiler (ADCP) (14-23 July); the Conductivity, Temperature, Depth (CTD) and turbulence data were obtained by a microstructure measuring system (MSS), and the nutrient samples were collected during the anchor station studies on 14-15 (A1), 16-17 (A2), and 21 July (A3) (Table 1). In addition, the wind data at the $10 \mathrm{~m}$ height with 10 min time interval were extracted from the R/V Aranda weather station data file.

The bottom mounted (at the $54 \mathrm{~m}$ depth) ADCP (RDI Narrow Band $600 \mathrm{kHz}$ ) was deployed by Pirkanmaa Regional Environmental Centre (Finland). The mooring position was chosen as close to the anchor station as possible. The bin size of $1 \mathrm{~m}$ and averaging over $15 \mathrm{~min}$ time interval were selected to obtain data 
Table 1. Date and duration of turbulence measurements at the anchor station studies, the number of nutrient profiles, and microstructure measuring system (MSS) sub-series and casts

\begin{tabular}{c|c|c|c|c}
\hline & $\begin{array}{c}\text { Date } \\
\text { (July) }\end{array}$ & $\begin{array}{c}\text { Duration, } \\
\text { h }\end{array}$ & $\begin{array}{c}\text { No. of nutrient } \\
\text { profiles }\end{array}$ & $\begin{array}{c}\text { MSS } \\
\text { (sub-series/casts) }\end{array}$ \\
\hline A1 & $14-15$ & 13 & 3 & $14 / 80$ \\
A2 & $16-17$ & 22 & 9 & $22 / 132$ \\
A3 & 21 & 14 & 6 & $14 / 96$
\end{tabular}

from 50 to $7 \mathrm{~m}$ depths. The measurement series with the MSS profiler were conducted on hourly basis, i.e. the sub-series consisted of six consecutive profiles per hour. The MSS profiler was equipped with CTD sensors to obtain highresolution temperature, salinity, and density profiles and with a shear probe (time constant approx. $3 \mathrm{~ms}$ ) measuring current velocity fluctuations (Prandke \& Stips, 1998). From the latter, the viscous dissipation rate of turbulent kinetic energy, $\varepsilon\left(\varepsilon=7.5 v<(\partial u / \partial z)^{2}>\right.$, where $v$ is kinematic viscosity, $\partial u / \partial z$ is vertical profile of current shear fluctuations, and $<>$ denote averaging), was calculated with relative error of about $30 \%$ as detailed in Prandke \& Stips (1998). The data were sampled at a frequency of $1024 \mathrm{~Hz}$. To avoid cable-induced disturbances the data were collected in freely sinking mode within depths of 5 to $55 \mathrm{~m}$ with the sinking speed of $0.6 \mathrm{~m} \mathrm{~s}^{-1}$. However, to avoid possible disturbances by the ship (though the ship was anchored by three anchors and its engine was switched off), the turbulence data only from below the $10 \mathrm{~m}$ depth were taken into account. To reduce the noise and ensure the comparability (turbulence sub-series time interval was $1 \mathrm{~h}$ and current data depth resolution $1 \mathrm{~m}$ ), all small- and meso-scale resolving data sets were averaged onto $1 \mathrm{~m}$ times $1 \mathrm{~h}$ grid and then filtered by the low-pass Butterworth filter with $4 \mathrm{~m}$ cutoff in vertical direction and $2 \mathrm{~h}$ cutoff in time. The filter cutoff scales were determined from the current data rotary spectra analysis where the white noise appeared at scales less than $4 \mathrm{~m}$ and $1 \mathrm{~h}$.

Nutrients were sampled with a rosette sampler from depths of 5, 10, 15, 20, $22.5,25,27.5,30,32.5,35,37.5,40$, and $50 \mathrm{~m}$ nearly every second hour. The phosphate and nitrate concentrations were determined following the guidelines for the second stage of the Baltic Monitoring Programme (BMEPC, 1983). The smoothing spline technique was used to interpolate nutrient data to $1 \mathrm{~m}$ vertical step.

\section{RESULTS AND DISCUSSION}

\section{Three different mixing conditions}

In respect to the wind speed the microstructure measurements were performed under three different wind forcing conditions: rising strong wind (A1), weak wind (A2), and decreasing strong wind (A3) (Fig. 2). The series mean kinetic energy 


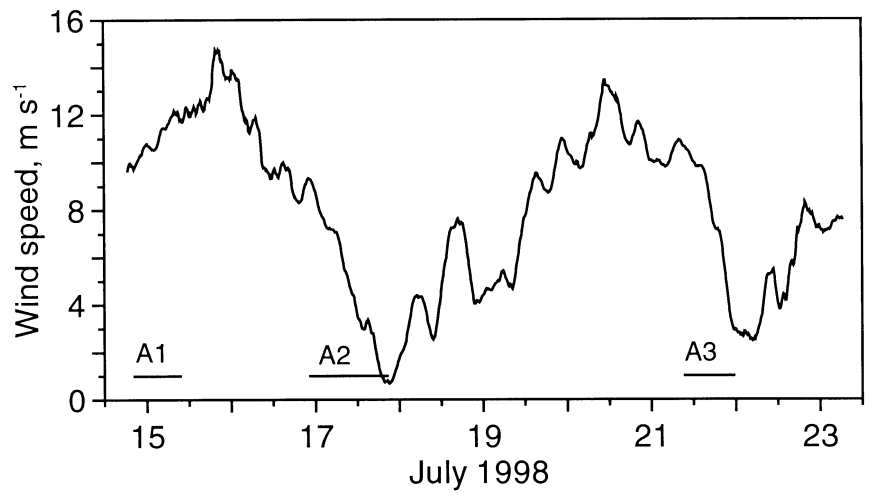

Fig. 2. Three hour average wind speed during the measurement period. Segments mark series A1, $\mathrm{A} 2$, and $\mathrm{A} 3$.

and velocity shear $\left(s=\left[(\partial u / \partial z)^{2}+(\partial v / \partial z)^{2}\right]^{1 / 2}\right)$ behaved in accordance with the mean wind stress: the highest values belonged to A1 and the lowest to A2 (Table 2). The mean stratification, influenced by the meso-scale flow, behaved differently - the stratification was the weakest during the A3 series. Thus, in terms of generation of turbulence, in the case of A2 turbulence was presumably weakly developed because of the weakest wind forcing, the weakest shear, and medium stratification. In the case of A1 a well-developed turbulence is expected because of the strong shear caused by the strong wind forcing. In the case of A3 the weak stratification and relatively strong shear were the factors supporting turbulence. In the last case the relative contribution from inertial waves was the highest.

Vertical changes of both temperature and salinity were important to determine the vertical distribution of density (Fig. 3).

Table 2. Mean characteristics of wind and kinetic energy, vertical shear, and buoyancy frequency in the water column from 10 to $50 \mathrm{~m}$ depth during the three anchor station studies

\begin{tabular}{l|c|c|c}
\hline & $\mathrm{A} 1$ & $\mathrm{~A} 2$ & $\mathrm{~A} 3$ \\
\hline Wind speed, $\mathrm{m} \mathrm{s}^{-1}$ & 11 & 5 & 8 \\
Wind stress, $\mathrm{N} \mathrm{m}^{-2}$ & 0.20 & 0.04 & 0.10 \\
Kinetic energy, $10^{-4} \mathrm{~J} \mathrm{~kg}^{-1}$ & 76.4 & 15.7 & 45.8 \\
Inertial kinetic energy, $10^{-4} \mathrm{~J} \mathrm{~kg}^{-1}$ & 15.1 & 1.4 & 18.6 \\
Shear squared, $10^{-4} \mathrm{~s}^{-2}$ & 3.7 & 1.4 & 2.9 \\
Buoyancy frequency squared, $10^{-4} \mathrm{~s}^{-2}$ & 6.1 & 4.5 & 4.1
\end{tabular}




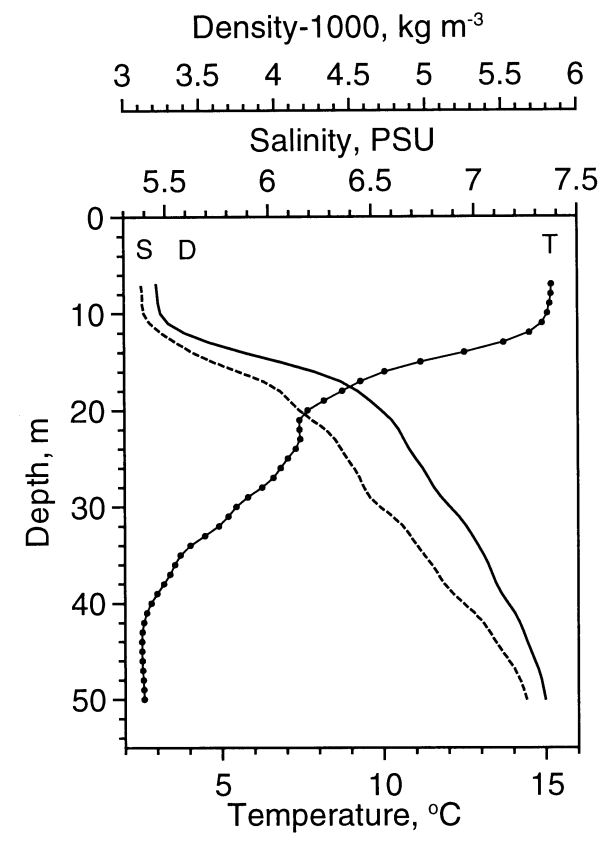

Fig. 3. Time average vertical profiles of the temperature $(\mathrm{T})$, salinity $(\mathrm{S})$, and potential density (D) for series A1.

\section{Eddy diffusivity}

The vertical eddy diffusivity of substance, the key parameter for calculating vertical fluxes, was estimated on the basis of the Osborn (1980) model $K_{\rho}=0.2 \varepsilon / N^{2}$, where $N^{2}\left(N^{2}=-g / \rho \partial \rho / \partial z\right.$, where $g$ is the gravity acceleration and $\rho$ is water density) is the buoyancy frequency squared. The model assumes a local production-dissipation balance and therefore the eddy diffusivity was calculated for the layer below the maximum of buoyancy frequency where we assume the Osborn model to apply. Because of the intermittent nature of small-scale turbulence, the mean eddy diffusivity profiles were calculated over individual profiles (henceforth $K_{\rho}$ denotes the mean eddy diffusivity). To calculate substance fluxes into the UML, $K_{\mathrm{\rho}}$ profiles were prolonged up to the sea surface assuming that the eddy diffusivity is approximately equal to the eddy viscosity, $K_{\mathrm{m}}$, in the UML. This approach is widely used for layers with the gradient Richardson number $\left(R i=N^{2} / s^{2}\right)$ less than 0.2 (Meier, 2001), which is just the case for UML. The eddy viscosity $K_{\mathrm{m}}$ was estimated using Csanady's approach according to which the eddy viscosity is a function of wind stress only, $K_{\mathrm{m}}=u^{* 2} / 200 f$, in the upper mixed layer (Csanady, 1982). Here $u^{*}\left(u^{*}=(\tau / \rho)^{1 / 2}\right.$, where $\tau$ is wind stress) is the mean surface friction velocity for the series and $f$ is the Coriolis parameter.

Below the UML the mean eddy diffusivity profile had its local minimum in the pycnocline at the $17-18 \mathrm{~m}$ depth, and below the $21 \mathrm{~m}$ depth it remained moderately variable, within the range $10^{-5}-10^{-4} \mathrm{~m}^{2} \mathrm{~s}^{-1}$ (Fig. 4). However, in that layer all three mean profiles, corresponding to the cases A1, A2, and A3, were 
Fig. 4. Time averaged eddy diffusivity profiles for series A1, A2, and A3. $K_{\rho}$ was calculated according to the Osborn model below the layer of the maximum buoyancy frequency $(15-17 \mathrm{~m})$. In the UML $K_{\rho}$ (straight sections of the curves) was taken equal to $K_{\mathrm{m}}$, while the latter was calculated according to Csanady's approach, and $K_{\rho}$ was interpolated between 15-17 m and UML.

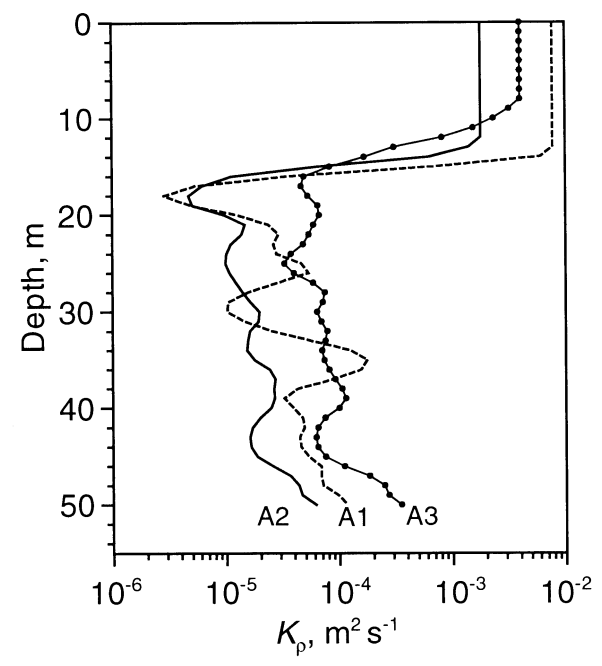

significantly separated from one another. Relative to the weakest level of turbulence in the case of A2, an increase of $K_{\rho}$ was observed in A1 because of the strong current shear and in A3 because of the relatively strong shear with the largest contribution from inertial waves and the weakest stratification (Table 2).

\section{Vertical distribution of nutrients}

The mean phosphocline in all three cases was slightly below the pycnocline, and the nitracline began even as deep as at the $25 \mathrm{~m}$ depth and deepened in the course of observations (Fig. 5). According to Laanemets et al. (2001) the phosphocline is typically situated in the upper part of the seasonal thermocline and the nitracline is about $5 \mathrm{~m}$ deeper at the entrance area to the Gulf of Finland in mid-summer.

\section{Vertical distribution of nutrient fluxes}

Relying on the gradient hypothesis the vertical turbulent flux of a nutrient can be estimated as $J=-K_{\rho} \partial C_{\mathrm{m}} / \partial z$, where $C_{\mathrm{m}}$ is the series mean concentration of the nutrient.

There were no nitrate fluxes close to the UML because of the deep nitracline for all three time series (Fig. 5). The maximum phosphate fluxes appeared just at the beginning of the pycnocline and were very variable below the UML. However, the fluxes were in accordance with the forcing, the smallest fluxes corresponded to series A2 and the largest to series A1. The flux profiles showed also that there was no layer with an about constant nutrient flux right below the 

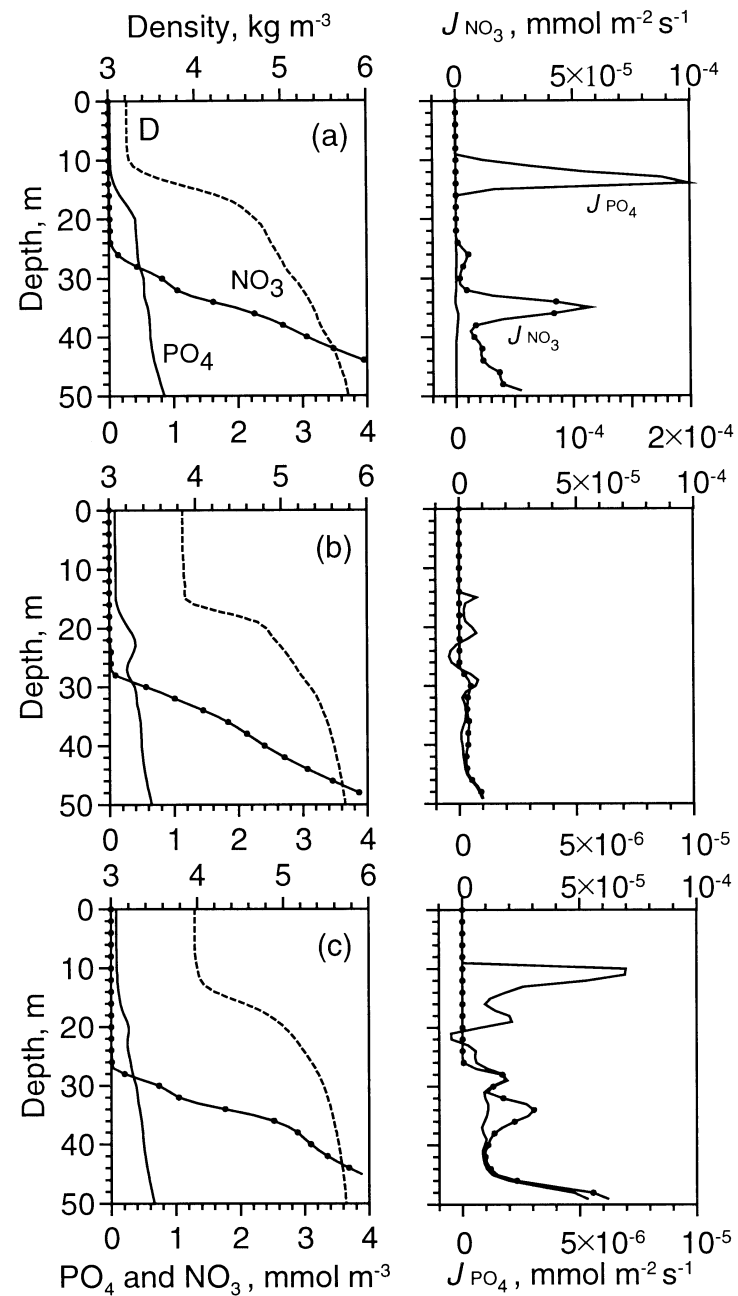

Fig. 5. Averaged over the sampling periods A1 (a), A2 (b), and $\mathrm{A} 3$ (c) vertical profiles of the potential density (dotted curve), nitrate (curve with filled circles), phosphate (bold curve), nitrate flux $J_{\mathrm{NO} 3}$ (curve with filled circles), and phosphate flux $J_{\mathrm{PO} 4}$ (bold curve).

bottom of the UML. Thus, the estimate of the amount of nutrients transferred into the UML, based on flux calculations, is very sensitive to the choice of reference depth. However, this method has been used, for example, to estimate the diffusive time scale of salinity anomalies where the flux is less depth dependent (Peters \& Bokhorst, 2001).

Calculation of the flux into the UML

The change of phosphate and nitrate concentrations in the UML can be estimated by solving numerically the following simplified conservation equation for nutrient concentration, $C, \partial C / \partial t=\partial / \partial z\left(K_{\rho} \partial C / \partial z\right)$. The applied boundary 
conditions at the surface and bottom were $K_{\rho} \partial C / \partial z=0$, and the first splined nutrient profile of the series was used as the initial condition $(t=0)$. The equation describes the nutrient concentration change in time due to the vertical turbulent mixing only; all other factors including sinks and sources are neglected. The initial and the calculated after one day profiles of phosphate and nitrate concentrations for the three time series are depicted in Fig. 6. In the UML the largest phosphate concentration change took place in the case of A1 and the smallest in the case of A2. The nutrient flux through a predefined reference level sums up from the concentration increments within the day from the surface to the reference level. The calculated phosphate fluxes through the UML bottom are given in Table 3. The phosphate flux in the case of the high wind speed (A1) exceeds the low wind speed case (A2) about 10 times. The calculated nitrate concentration did not change in the UML for all wind forcing regimes, i.e. in the case of a deep nitracline, as observed in 1998, short strong wind events are not able to mix nitrate into the UML.

Phosphate concentration reached minimum values, almost below the detection level, in the upper layer by the middle of July (e.g. HELCOM, 2002). According to estimates by Larsson et al. (2001), the concentration sufficient for the formation of a Nodularia bloom is about $0.05 \mathrm{mmol} \mathrm{m}^{-3}$. A relatively strong wind event lasting for a day can result in an increase of the phosphate concentration by $\sim 0.03 \mathrm{mmol} \mathrm{m}^{-3}$ (Table 3), which is about a half what is needed for the bloom formation. That increase gives an estimate of roughly 230 tonnes of internal phosphorus input over the entire gulf area at the $10 \mathrm{~m}$ depth $\left(\sim 25000 \mathrm{~km}^{2}\right)$. From the total annual load the average external phosphorus input to the gulf, mainly to the coastal sea areas, is approximately 630 tonnes per month (HELCOM, 2002). These very rough estimates point to the potential of turbulent mixing to alleviate cyanobacteria phosphorus deficiency in the late summer UML.

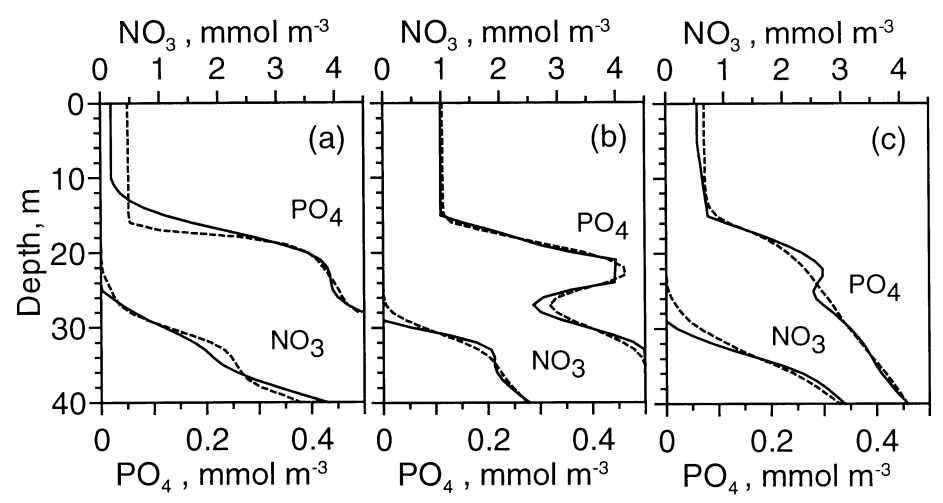

Fig. 6. Splined profiles of phosphate and nitrate (bold curves) sampled at the beginning of series A1 (a), A2 (b), and A3 (c) respectively and serving for initial conditions for the diffusion equation. The dotted curves depict simulated phosphate and nitrate profiles after one day calculation. 
Table 3. Mean wind speed $U\left(\mathrm{~m} \mathrm{~s}^{-1}\right)$, UML depth (m), phosphate flux through the UML bottom $\left(\mathrm{mmol} \mathrm{m} \mathrm{d}^{-1}\right)$, initial phosphate concentration in the UML $\left(\mathrm{mmol} \mathrm{m}^{-3}\right)$, phosphate concentration in the UML after $1 \mathrm{~d}$ integration of diffusion equation $\left(\mathrm{mmol} \mathrm{m}^{-3}\right)$, and increment of phosphate concentration in the UML $\left(\mathrm{mmol} \mathrm{m}^{-3}\right)$

\begin{tabular}{c|r|c|c|c|c|c}
\hline & $U$ & $\begin{array}{c}\text { UML } \\
\text { depth }\end{array}$ & Flux & $\begin{array}{c}\text { Initial } \\
\text { concentrations }\end{array}$ & $\begin{array}{c}\text { Concentration } \\
\text { after 1 d }\end{array}$ & Increment \\
\hline A1 & 11 & 10 & 0.32 & 0.02 & 0.05 & 0.03 \\
A2 & 5 & 17 & 0.02 & 0.11 & 0.11 & 0.0 \\
A3 & 8 & 10 & 0.11 & 0.06 & 0.07 & 0.01
\end{tabular}

Therefore, strong wind events may cause considerable internal phosphate transport into the summer UML, especially important for the open gulf areas where the actual massive cyanobacterial blooms are usually observed. Consequently, the inter-annual changes in summer wind conditions over the western gulf area are of interest. The following analysis is based on Utö weather station data (Finnish Meteorological Institute), which we assume, relying on the previous field-work experience of e.g. Pavelson et al. (1997), representative for the western gulf area. The wind-mixing energy in May-July and separately in July was calculated for the period 1982-2001 from $E=\gamma \rho_{\mathrm{a}} C_{\mathrm{a}} \int|\mathbf{u}|^{3} \mathrm{~d} t$. Here $\gamma=10^{-3}$ is the dimensionless wind mixing efficiency parameter, $\rho_{\mathrm{a}}$ is the air density, $C_{\mathrm{a}}=1.2 \times 10^{-3}$ is the wind drag coefficient and $|\mathbf{u}|$ is the wind velocity vector modulus. The windmixing energy in May-July almost doubled in 1997-2001 (Fig. 7). This was mainly due to the increase in wind speed in May-June while the increase in July was less pronounced. Also, 3-5 stronger wind events for the period from the middle of June to the middle of July can be found from the wind record. Thus, it can be supposed that the phosphorus input from below the thermocline caused by turbulent mixing increased during those years and likely contributed to the heavy cyanobacterial blooms observed during the last warm summers.

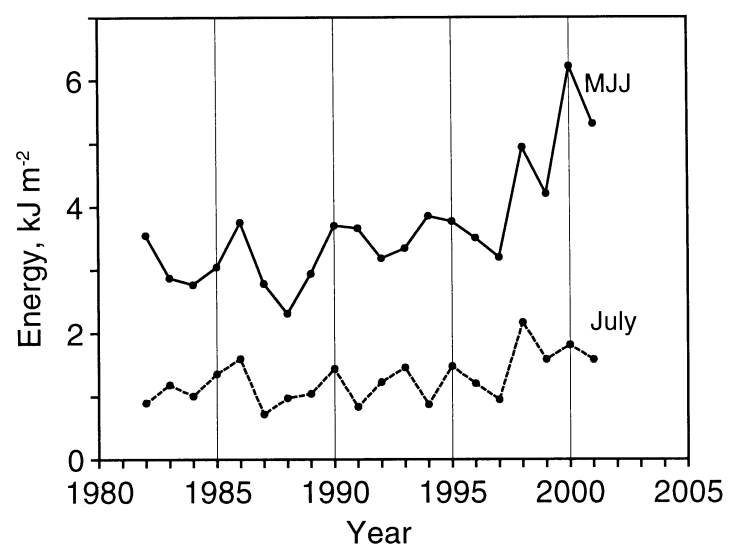

Fig. 7. Integrated wind-mixing energy for the periods May-July (MJJ) and July for the years 1982 to 2001 . 


\section{CONCLUSIONS}

In general, strong thermal stratification effectively restricted vertical transport of nutrients from deeper layers in late summer. Nevertheless, direct measurements of turbulence showed that a strong wind event was capable of generating a phosphate flux into the UML comparable with the phosphate demand of Nodularia to form a bloom. The following main conclusions can be drawn.

- Turbulent nutrient fluxes into the UML are strongly dependent on both the relative vertical location of the nutricline versus the pycnocline and the vertical distribution of the eddy diffusivity coefficient $K_{\rho}$.

- Strong wind events (average wind speed exceeding $10 \mathrm{~m} \mathrm{~s}^{-1}$ ) generate relatively large phosphate fluxes into the UML while the nitrate fluxes remain insignificant due to the deeper location of the nitracline.

- Consequently, the vertical turbulent mixing transfers nutrients to the UML with a very low N:P ratio in late summer, i.e. favours especially Nodularia blooms in warm summers.

\section{ACKNOWLEDGEMENTS}

The data were collected in the frame of the EC-MAST3 project MITEC. We thank the officers and the crew of the R/V Aranda for their cooperation and flexibility during the cruise. Likewise, our thanks to Timo Huttula, who kindly provided ADCP data, and to Aleksander Toompuu for valuable comments on the manuscript. The comments of two anonymous referees helped us to improve our paper. The Maj and Tor Nessling Foundation and EC project HABES financially supported this work.

\section{REFERENCES}

Alenius, P., Myrberg, K. \& Nekrasov, A. 1998. Physical oceanography of the Gulf of Finland: a review. Boreal Environ. Res., 3, 97-129.

BMEPC. 1983. Guidelines for the Baltic monitoring programme for the second stage. Baltic Sea Environ. Proc., 12.

Csanady, G. T. 1982. Circulation in the Coastal Ocean. D. Reidel Publishing Company, Dordrecht.

Gade, H. G. 1970. Hydrographic investigations in the Oslofjord, a study of water circulation and exchange processes. In Report 24, pp. 193. Geophys. Inst. Div. A, Univ. Bergen.

Hela, I. 1966. Vertical eddy diffusivity of waters in the Baltic Sea. Geophysica, 9, 219-234.

HELCOM. 2002. Environment of the Baltic Sea area 1994-1998. Baltic Sea Environ. Proc., 82B.

Kononen, K., Kuparinen, J., Mäkelä, K., Laanemets, J., Pavelson, J. \& Nõmmann, S. 1996. Initiation of cyanobacterial blooms in the frontal region at the entrance to the Gulf of Finland, Baltic Sea. Limnol. Oceanogr., 41, 98-112.

Kullenberg, G. E. B. 1977. Observation of the mixing in the Baltic thermo- and halocline layers. Tellus, 29, 572-587.

Kullenberg, G. E. B. 1981. Physical oceanography. In The Baltic Sea (Voipio, A., ed.), pp. 135181. Elsevier, Amsterdam.

Kullenberg, G. E. B. 1982. Mixing in the Baltic Sea and implications for the environmental conditions. In Hydrodynamics of Semi-enclosed Seas (Nihoul, J. C. J., ed.), pp. 399-418. Elsevier, Amsterdam. 
Laanemets, J., Pavelson, J., Poutanen, E.-L. \& Kononen, K. 2001. Seasonal nutricline in the Gulf of Finland: some characteristics and response to the mesoscale physical forcing. In Abstract Volume, Baltic Sea Science Congress 2001, November 25-29, Stockholm, Sweden, p. 236.

Larsson, U., Hajdu, S., Walve, J. \& Elmgren, R. 2001. Baltic Sea nitrogen fixation estimated from the summer increase in upper mixed layer total nitrogen. Limnol. Oceanogr., 46, 811-820.

Lilover, M.-J. \& Nabatov, V. N. 1990. On the turbulent mixing in the frontal zone of the Baltic Sea. In Proceedings of the 3-d All-Union Symposium on Finestructure and Synoptic Variability of the Sea, pp. 96-97. Tallinn (in Russian).

Matthäus, W. 1990. Mixing across the primary Baltic halocline. Beitr. Meereskd., 61, 21-31.

Meier, H. E. M. 2001. On the parameterization of mixing in three-dimensional Baltic Sea models. J. Geophys. Res., 106, 30997-31016.

Osborn, T. 1980. Estimates of the local rate of vertical diffusion from dissipation measurements. J. Phys. Oceanogr., 10, 83-89.

Palmén, E. 1930. Untersuchungen über die Strömungen in den Finnland umgebenden Meeren. Comm. Phys.-Math., 12, Soc. Sci. Fenn.

Pavelson, J., Laanemets, J., Kononen, K. \& Nõmmann, S. 1997. Quasi-permanent density front at the entrance to the Gulf of Finland: response to the wind forcing. Cont. Shelf Res., 17, 253-265.

Peters, H. \& Bokhorst, R. 2001. Microstructure observations of turbulent mixing in a partially mixed estury. Part II: salt flux and stress. J. Phys. Oceanogr., 31, 1105-1119.

Prandke, H. \& Stips, A. 1998. Test measurements with an operational Microstructure-Turbulence profiler: detection limit of dissipation rates. Aquat. Sci., 60, 191-209.

Rahm, L. 1985. On the diffusive salt flux of the Baltic proper. Tellus, 37A, 87-96.

Shaffer, G. 1979. Conservation calculations in natural coordinates (with an example from the Baltic). J. Phys. Oceanogr., 9, 847-855.

Stigebrandt, A. 1987. A model for the vertical circulation of the Baltic deep water. J. Phys. Oceanogr., 17, 1772-1785.

Zülicke, C., Hagen, E. \& Stips, A. 1998. Dissipation and mixing in a coastal jet: a Baltic Sea case study. Aquat. Sci., 60, 220-235.

\title{
Soome lahe hilissuviste toitainevoogude hinnang turbulentsi mõõtmise põhjal
}

\author{
Madis-Jaak Lilover, Jaan Laanemets, Tiit Kullas, Adolf Stips \\ ja Kaisa Kononen
}

Uurimislaeval Aranda (Soome Mereuurimise Instituut) tehti Soome lahe suudmealal juulis 1998 kolm mõõtmisseeriat, mille käigus mõõdeti toitainete, hoovuse kiiruse, temperatuuri, soolsuse ja turbulentsi vertikaalsed profiilid. Mõõtmised toimusid erinevates tuuleoludes. Ülemises segunenud kihis olid turbulentse difusiooni vertikaalsel koefitsiendil, $K_{\rho}$, suhteliselt suured väärtused $\left(2-8 \times 10^{-3} \mathrm{~m}^{2} \mathrm{~s}^{-1}\right)$ vastavalt keskmisele tuule tugevusele. Allpool sesoonset tiheduse hüppekihti varieerus seeria keskmine $K_{\mathrm{\rho}}$ vahemikus $10^{-6}-10^{-4} \mathrm{~m}^{2} \mathrm{~s}^{-1}$. Ülemisse segunenud kihti turbulentse segunemise poolt transporditud toitainete hulka hinnati lihtsustatud difusioonivõrrandi lahendamise kaudu, kasutades seeria keskmist arvutatud $K_{\rho}$ profiili ja algtingimusena mõõdetud toitainete kontsentratsiooni jaotust. Selgus, et fosfaatide ja nitraatide hüppekihtide suure eraldatuse tõttu olid toitainete vood ülemisse segunenud kihti suure fosfaatide ülejäägiga (Redfieldi suhte mõttes). Soojadel suvedel soodustab see sinivetikate massilist vohamist. 